ПСИХОЛОГІЧНІ ЧИННИКИ, ЯКІ ВПЛИВАЮТЬ НА САМОТНІСТЬ РЕЛІГІЙНИХ ЖІНОК

\title{
PSYCHOLOGICAL FACTORS AFFECTING ON THE LONELINESS OF RELIGIOUS WOMEN
}

у статті наведено результати дослідження особливостей переживання самотності релігійними жінками.

Виявлено, що в релігійних жінок найвищий рівень самотності спостерігається у взаємодії із соціумом, у сімейних сосунках, а також у стосунках із партнером. Отриманий низький рівень загального показника самотності обгрунтовано почуттям приналежності до стійкої соціальної групи релігійних осіб, що виступає ресурсом психологічної захищеності особистості жінки, де вона отримує розраду, душевний комфорт, долає свої негативні переживання, стреси, життєві кризи й втрату сенсу життя, тим самим наділяє цінністю релігійну спілку. Показано на рівні тенденції, що на самот ність релігійних жінок впливає орормування спільності «Ми - Вони», яка виступає чинником від'єднання та відокремлення себе від загального середовища з прагненням до духовності, високої моральності й любові в єднанні з Богом.

Установлено, що самотність у соціумі, сім'ї, з партнером зумовлена зв'язком із недостатністю взаємостосунків через порушення емоційної інтеріоризації жіночо-чоловічої гендерної ролі, яка є наслідком негативної оцінки свого образу й відмови від своєї явно вираженої гендерної ідентичності. Показано на рівні тенденції, що на Я-концепію релігійних жінок впливають принципи й духовно-моральні цінності в релігійних спільHomax.

Установлено, що на суб'єктивний чинник «страх залишитися самій» впливає об'єктивний чинник - страх втрати домінівну в соціальному оточенні групу релігійно налаштованих людей (захист і підтримку).

Виявлено індивідуально-особистісні риси жіночої групи, які мають зв'язок із почут тям самотності. Переживання самотності зумовлене відчуттям некмітливості, недружності, відчаєм і розгубленістю, які є наслідком їхньої закритості й усамітнення в соціальному середовищі.

Наведені незадоволені потреби в жіночо групи, які мають безпосередній зв'язок із самотністю, де потреба в безпеці, в повазі з боку інших і в умінні співвідносити свої бажання, можливості й прагнення до здійснення мети задовольняються ані в соціумі, ані з партнером, а саме в спільноті релігійних осіб.

Показаний взаємозв'язок між самотністю та причинами й установками, де страх і тривога є наслідками бар'єра в спілкуванні, саморозкритті, взаєморозумінні, в повазі, емоційних контактах, у відкритості - можливості зрозуміти й прийняти їх іншими особами. А пригніченість і нереалізованість потреб блокує особистісне зростання та становлення самосвідомості, ідентифікацію особистості, об'єктивізацію самооцінки, спричиняючи виникненню таких психологічних проблем, як депресія, відчай, бажання ізолюватись від оточення.

Ключові слова: самотність, релігійні жінки, психологічні чинники, індивідуально-особи- стісні властивості, мотиви, потреби, взаємостосунки, суб'єктивні причини.

The article presents the results of a study of the peculiarities of experiencing loneliness by religious women.

It was found that religious women have the highest level of loneliness in interaction with society, in family relationships, as well as in relationships with a partner. The obtained low level of the general indicator of loneliness is substantiated by the feeling of belonging to a stable social group of religious persons, which serves as a resource of psychological protection of a woman's personality, where she receives consolation, emotional comfort, overcomes her negative experiences, stress, life crises and loss of meaning. the value of a religious union.

It is shown at the level of the tendency that the Ioneliness of religious women is influenced by the formation of the community "We-They", which is a factor of separation, and separation from the general environment with a desire for spirituality, high morality and love in union with God.

It is established that loneliness in society, family, with a partner is due to the lack of interpersonal relationships, due to the violation of the emotional internalization of female-male gender role, which is a consequence of negative evaluation of their image and rejection of their explicit gender identity. It is shown that at the level of the tendency that the self-concept of religious women is influenced by the principles and spiritual and moral values in religious communities.

It has been established that the subjective factor "fear of being alone" is influenced by an objective factor - the fear of losing the dominant group of religiously-minded people in the social environment (protection and support).

Individual-personal features of the female group, which are connected with the feeling of loneliness, are revealed. The experience of loneliness is caused by feelings of ignorance, hostility, despair and confusion, which are a consequence of their secrecy and solitude in the social environment.

The unmet needs of the female group, which are directly related to loneliness, are listed. Where the need for security, respect from others and the ability to balance their desires, opportunities and aspirations to achieve the goal, are met neither in society nor with a partner, namely in the union of religious persons.

The relationship between loneliness and causes and attitudes is shown, where fear and anxiety are the consequences of a barrier in communication, self-disclosure, mutual understanding respect, emotional contact, openness - the ability for others to understand and accept them. And the depression and unrealization of these needs blocks personal growth and the formation of self-awareness, personal identification, objectification of self-esteem, causing psychological problems such as depression, despair, the desire to isolate themselves from others.

Key words: loneliness, religious women, psychological factors, individual and personal characteristics, motives, needs, interpersonal relationships, subjective reasons. 
Постановка проблеми. Почуття самотності є важливою складовою частиною людського життя. Нині проблема самотності актуальна через постіндустріальну епоху, коли відбувалися корінні зміни в соціальних інститутах, інститутах сім'ї, індивідуалізації суспільства, в баченні світу й зростанні економічного добробуту в розвинених країнах. Спираючись на результати опитування, проведеного Ю.М Швалб та О.В. Данчевою, серед різних людей за статтю, віком, освітою та соціальним становищем, було виявлено, що впродовж останніх років словами-символами у $83 \%$ осіб опитуваних були «самотність», «відчуження», «особистість» [10].

Як обґрунтовано стверджує радянський філосо $\varnothing$ А.І. Титаренко, «<...> проблема самотності у XX столітті набула небувалого за значенням філософсько-етичного статусу, побачивши в ній фатальне джерело не тільки трагічної безнадійності існування людини, а й ходу всієї історії людства» [8, с. 21].

Аналіз останніх досліджень і публікацій. Аналіз численних досліджень дозволяє говорити про те, що самотність розглядається у двох аспектах: як психологічний стан людини (внутрішнє емоційне переживання) та як характеристика її фізичних відносин з іншими людьми, зовнішне відчуження від суспільства (В.І. Сіляєва, Н.Є. Харламенкова, І.В. Бабанова, 1999 рік) [6, с. 33-35; 9, с. 21-28].

Дослідники Ю.М. Швалб та О.В. Данчева [10] виокремлюють три основні форми самотності: 1. Обряди, ритуали, випробування, виховання самотністю, які відбувалися практично у всіх племен і народів; 2. Покарання самотністю, що виражалося у вигнанні з роду й прирікало покараного майже на вірну смерть; 3. Добровільне усамітнення окремих індивідів, відлюдництво (духовне збагачення, вихід від мирських справ).

У своєму досліджені болгарський психолог Л. Сімеонова [7, с. 11] зробила спробу згрупувати типи поведінки людей, схильних до самотності: 1) ненаситна потреба людини в самоствердженні (центр уваги - власний успіх); 2) одноманітність у поведінці (наприклад, обрана соціальна роль); 3) зосередженість людини на своїх відчуттях (недовірлива, сповнена похмурих передчуттів, полонена панічним страхом за своє здоров'я тощо); 4) нестандартність поведінки, коли світосприйняття та вчинки не відповідають встановленим у групі правилам і нормам (своєрідність бачення світу або небажання рахуватися з іншими); 5) недооцінка себе як особистості (нецікавий іншим).

Численні дослідження говорять про те, що релігія відбивається в психіці людини, яка її прийняла, як релігійність - соціально-психологічна властивість особистості, суб'єктивне відбиття, ступінь прийняття елементів релі- гії, які проявляються у свідомості й поведінці особистості (Е.А. Колякина, Ю.Ф. Борунков, I.M. Яблоков, R.A. Emmons, R.F. Paloutzian, M. Argyle) $[3 ; 1 ; 13 ; 12]$. Релігійність, як стверджують дослідники Е.А. Ходжаева, Е.А. Шумилова [4], містить у собі 5 компонентів: когнітивний (знання, вірування, переконання); емоційний (почуття та емоції, пов'язані з вірою); поведінковий (культова поведінка: обряди, ритуали); ідентифікаційний (усвідомлення людиною своєї приналежності до певної конфесії та віри) й нормативно-ціннісний.

Виділяючи в релігії соціальні й психологічні функції, які пов'язані з безпекою особистості, спираючись на те, як релігія діє на особистість, а не яке має значення для неї, дослідники Д.В. Ольшанський, Ю.Ф. Борунков, І.М. Яблоков, Е.С. Шірокалова, Peterson, Seligman вказують на компенсаторну функцію релігії, яка виражається в підтримці й надії на допомогу Бога особистості в складних життєвих ситуаціях $[5 ; 1 ; 11 ; 14]$.

Дослідник О.І. Донцов [2, с. 187-196], який присвятив свої роботи психологічним особливостям православної сім'ї, виділив такі компоненти: 1. Для людини уцерковленої в сімейних відносинах пріоритетом виступає емоційно-чуттєва сфера, а не комунікативна, як в інших людей; 2. Мотиваційна і ціннісно-моральна сфери в релігійній сім'ї значною мірою розвиваються відповідно до орієнтирів, що задаються релігійним світосприйняттям прагненням до духовності та єднання з Божественним, високою моральністю та любов'ю, в той час, як для інших людей пріоритетами $€$ саморозвиток, цілеспрямованість, особисті досягнення та здоров'я.

Релігійність формує специфічну конфесію ціннісно-нормативної системи особистості, особливості мислення, поведінки, стратегії адаптації, відокремлення та усамітнення в соціумі, стилю життя в цілому. 3 боку духовно-моральних ідеалів принцип індивідуалізації розуміється як те, що містить у собі загрозу відходу особистості в егоїзм, що в релігії не припустимо й сприймається як гріх (M. Argyle, 2000 рік; О.І. Донцов, 2010 рік) [12; 2].

Зважаючи на нинішній стан розробленості проблеми щодо того, як впливає релігія на особистість, слід зазначити, що відкритим залишається питання стосовно того, наскільки релігійна людина почуває себе самотньою в соціумі та які чинники приводять до виникнення в неї почуття самотності.

Постановка завдання. Мета статті полягає у виявленні психологічних чинників, які впливають на виникнення почуття самотності в релігійних жінок.

Виклад основного матеріалу дослідження. У ході емпіричного дослідження використовувався такий психодіагностичний 
інструментарій: Фрайбурзький особистісний опитувальник F P I (форма В) А.О. Крилова й Т.І. Ронгінської (Вансовская, Гайда, Гербачевский, 1997 рік); особистісний опитувальник емоційного ставлення А.Т. Джерсайлда (Колесникова, 2019 рік); методика діагностики комунікативної соціальної компетентності (далі - КСК) М.П. Фетіскіна, В.В. Козлова, Г.М. Мануйлова (Фетискин, Козлов, Мануйлов, 2002 рік); методика актуальності основних потреб у модифікації І.О. Акіндінової (Пугачев, 2003 рік); тест сенсожиттєвих орієнтацій (далі - СЖО) Д.О. Леонтьєва (Леонтьев, 2000 рік); DLS (Differential Loneliness Scale) (Тихонов, 2006 рік); SELSA (Di Tommaso, Spinner, 1993 рік); методика суб'єктивної оцінки взаємостосунків СОМО С.В. Духновського (Духновский, 2006 рік); методика С. Бем маскулинність - фемінність (Практикум по гендерной психологии, 2003 рік); шкала інтимності Бернса (Тихонов, 2006 рік) і методика індексу якості життя Р.С. Еліота (Практикум по психологии здоровья, 2005 рік).

Вибірка: в дослідженні взяли участь 48 релігійних жінок. Основними критеріями уцерковленості жінок були: 1. Частота відвідувань - не менше 1 разу на тиждень; 2. Регулярне виконання церковних обрядів. Вік досліджуваних жінок складає від 25 до 45 років.

Для статистичної обробки даних використовувались описові статистики, U-критерій Манна-Уїтні, t-критерій Стьюдента, кореляційний аналіз. Обробка емпіричних даних здійснювалося за допомогою комп'ютерної програми SPSS 21.0 for Windows.

Результати й дискусія. На підставі аналізу даних: за опитувальником SELSA (Di Tommaso, Spinner, 1993 рік), особистісного опитувальника емоційного ставлення А.Т. Джерсайлда (Колесникова, 2019 рік) і шкали інтимності Бернса (Тихонов, 2006 рік) було виявлено рівень самотності в релігійних жінок (таблиця 1).

Таблиця 1

Показники самотності релігійних жінок

\begin{tabular}{|c|c|c|}
\hline & $\begin{array}{c}\text { Середнє } \\
\text { значення } \\
\text { (n=48) }\end{array}$ & $\begin{array}{c}\text { Стандартне } \\
\text { відхилення }\end{array}$ \\
\hline Соціальна самотність & 41,1 & 18,8 \\
\hline Сімейна самотність & 35,3 & 22,0 \\
\hline Романтична самотність & 45,2 & 15,3 \\
\hline Самотність & 1,4 & 1,5 \\
\hline Страх бути самій & 5,0 & 2,9 \\
\hline
\end{tabular}

Аналіз отриманих даних таблиці 1 показав, що в релігійних жінок, найвище середнє значення спостерігається за шкалою «соціальна самотність», а найнижче - за загальним показником «самотність». Отримані середні значення шкал можна ранжувати таким чином: соціальна самотність $(\mathrm{M}=41,1)$, сімейна самотність $(\mathrm{M}=35,3)$, романтична самотність $(M=45,2)$, страх бути самій $(M=5,0)$, самотність $(\mathrm{M}=1,4)$. Отримані значення за шкалами соціальна й сімейна самотність знаходяться на високому рівні (самотні), романтична самотність знаходиться на межі між помірно вираженим рівнем і високим рівнем, показники шкали страх бути самій перебуває на середньому рівні, а загальний показник самотності на слабо вираженому рівні.

Отже, можна говорити про те, що загальний показник самотності перебуває на слабо вираженому рівні, який обґрунтовується почуттям приналежності до стійкої соціальної групи релігійних осіб, що виступає ресурсом психологічної захищеності особистості. Але, спираючись на отримані показники, релігійні жінки відчувають самотність у соціумі, в сім'ї та навіть у партнерських стосунках. Це, з одного боку, може бути обумовлено тим, що домінівним орієнтиром виступає психологічна дихотомія в основі формування спільності «Ми - Вони», яка є чинником від'єднання та відокремлення себе від загального середовища й прагненням до духовності, високої моральності й любові в єднанні з Богом. Або засобом демонстрування своєї соціальної респектабельності, лояльності щодо загальноприйнятого способу життя. 3 іншого боку, самотність можна пояснити неможливістю знайти підтримку в оточенні в складних життєвих ситуаціях, що є підґрунтям вступу людини в релігійну спілку, де вона отримує розраду, душевний комфорт і долає свої негативні переживання, стреси, життєві кризи й втрату сенсу життя, тим самим наділяє цінністю релігійну громаду. А така цінність своєю чергою пояснює отриманий середній рівень страху залишитися самій, який обґрунтовується страхом втрати цієї спільноти.

Аналіз кореляційних зв'язків самотності з показниками взаємостосунків з індивідуально-особистісними рисами, 3 мотивами й потребами, причинами й установками показав наявність таких зв'язків (таблиця 2).

Отримані дані (таблиця 2) свідчать про те, що в групі релігійних жінок спостерігається зв'язок між самотністю та показниками взаємовідносин.

Де сімейна самотність має позитивний кореляційний зв'язок із романтичною (партнером) самотністю, загальний показник самотності позитивно корелює із соціальною самотністю та негативно - $з$ фемінністю та маскулінністю, страх залишитися самій має негативний кореляційний зв'язок із напруженістю в стосунках. Отже, можна говорити про те, що в релігійних жінок соціальна, сімейна, романтична самотність пов'язана 3 недостатністю взаємостосунків як у соціумі, так 
і з партнером. Також виявлено, що переживання самотності в соціумі має зв'язок із гендерною роллю «Я-концепція». Отриманий кореляційний взаємозв'язок узгоджується з припущенням про тенденції до «поляризації» образів чоловіка й жінки, яка зумовлена принципами й духовно-моральними цінностями про те, що індивідуалізм - це егоїзм, який є гріхом. Також це говорить про порушення емоційної інтеріоризації жіночо-чоловічої гендерної ролі, що є наслідком негативної оцінки свого образу й відмови від своєї явно вираженої гендерної ідентичності. Їх суб'єктивний чинник, страх залишитися самій зумовлений об'єктивним чинником соціальних умов, а саме соціокультурною детермінацією - моральністю. У становленні релігії вирішальним етапом $€$ поява зобов'язувальної вимоги «ти повинен» як «етичного чинника». Тому віра людини містить «етос»: поряд із чисто ритуальними вона надає руху етичних регуляторів поведінки, тим самим формуючи соціально пасивну, схильну до конформізму, «Богоугодну» поведінку. Також вона підкріплює страх у релігійної жінки залишитись самій і втратити домінівну в соціальному оточенні групу релігійно налаштованих людей через не виконання установлених правил поведінки - моральності.

Аналізуючи зв'язки між самотністю та показниками індивідуально-особистісних рис, можна говорити про те, що переживання самотності релігійних жінок насамперед пов'язане з такими індивідуально-особистісними рисами, як некмітливість, недружність, розчарування, відчай і розгубленість, які $€$ наслідком їх закритості й усамітнення в соціальному середовищі.

Аналіз кореляційного зв'язку виявив негативний зв'язок між соціальною самотністю та потребою в безпеці, а також позитивний зв'язок із гармонійністю реалізації базових прагнень Б, також виявлено негативний

Взаємозв'язок значень коефіцієнтів кореляції самотності

Таблиця 2 й досліджуваними показниками групи

\begin{tabular}{|c|c|c|c|c|c|}
\hline Показники & 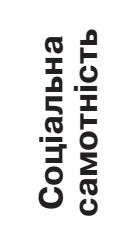 & 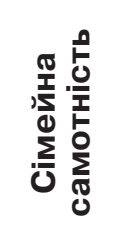 & 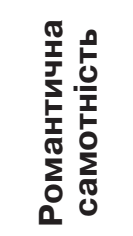 & $\begin{array}{l}0 \\
\frac{2}{0} \\
\bar{T} \\
\frac{0}{2} \\
0 \\
0\end{array}$ & 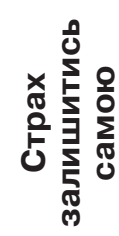 \\
\hline \multicolumn{6}{|c|}{ Показники взаємостосунків } \\
\hline Сімейна самотність & & & $0,40^{*}$ & & \\
\hline Романтична самотність & & $0,40^{*}$ & & & \\
\hline Напруженість у стосунках & & & & & $-0,40^{\star}$ \\
\hline Соціальна самотність & & & & $0,38^{*}$ & \\
\hline Маскулінність і фемінність & & & & $-0,40^{\star}$ & \\
\hline \multicolumn{6}{|c|}{$\begin{array}{l}\text { Індивідуально-особистісні риси } \\
\end{array}$} \\
\hline Самотність & $0,38^{*}$ & & & & \\
\hline $\begin{array}{c}\text { Кмітливий із розвитком логічного мислення } \\
\text { (VIII B) }\end{array}$ & & & $-0,40^{*}$ & & \\
\hline Комунікативність & & & $-0,51^{*}$ & & \\
\hline Безнадія & $0,44^{\star}$ & & & & \\
\hline \multicolumn{6}{|c|}{ Причини й установки } \\
\hline Відчай & & $0,37^{*}$ & & & \\
\hline Боязкість і соціальна тривога & & $0,37^{*}$ & & & \\
\hline Страх саморозкриття & & & 0,38 & & \\
\hline Депресія & & & & & $0,60^{* *}$ \\
\hline Відчуженість та ізольованість & & & & $0,42^{\star}$ & \\
\hline \multicolumn{6}{|c|}{ Мотиви й потреби } \\
\hline Потреба в безпеці & $-0,47^{* *}$ & & & & \\
\hline Гармонійність реалізації базових прагнень & $0,43^{\star}$ & & & & \\
\hline Потреба в повазі з боку інших (ої) & & & $-0,47^{* *}$ & & \\
\hline Процес & & & & & $0,38^{*}$ \\
\hline
\end{tabular}

Note: * $p<0,05$; ** $p<0,01$ 
зв'язок між романтичною самотністю та повагою з боку інших. Це свідчить про те, що виявлені потреби й мотиви жінок-вірян, а також уміння співвідносити свої бажання, можливості й прагнення до здійснення мети приводять до задоволення ні в соціумі, ні з партнером, а саме в спілці релігійних осіб, де релігія забезпечує безпеку вірянину, компенсуючи отримання поваги й своєї цінності істинною вірою, сприяючи суб'єктивному сприйманню власного добробуту.

Аналізуючи кореляційний зв'язок між самотністю та причинами й установками, був виявлений позитивний зв'язок між сімейною самотністю та відчаєм, боязкістю та соціальною тривогою, між романтичною самотністю та страхом розкриття, між самотністю та відчуженням, ізольованістю, а також між страхом залишитись самій і депресією. Це свідчить про те, що самотність у сімейних взаємовідносинах і стосунках між подружжям (партнером) обґрунтовано наявністю в релігійних жінок страху й тривоги, які виступають бар'єром у спілкуванні, саморозкритті, взаєморозумінні, прийнятті іншими, в повазі, емоціях та емоційних контактах, відкритості - можливості іншим зрозуміти їх. У разі пригніченості й нереалізованості потреб особистісне зростання та становлення самосвідомості, ідентифікація особистості, об'єктивізація самооцінки в релігійних жінок блокується, спричиняючи виникнення психологічних проблем, таких як депресія, відчай, бажання ізолюватись від оточення.

Висновки з проведеного дослідження. Таким чином, можна зробити висновки, що релігійним жінкам притаманна самотність. Виявлено, що найвищий рівень самотності релігійні жінки відчувають у соціумі, сім'ї та навіть у партнерських стосунках, що зумовлено страхом саморозкриття, бар'єрами в спілкуванні, неможливістю знайти підтримку в оточенні в складних життєвих ситуаціях.

Установлений низький рівень за загальним показником самотності обґрунтовується почуттям приналежності до стійкої соціальної групи релігійних осіб, що виступає ресурсом психологічної захищеності особистості жінки, де вона отримує розраду, душевний комфорт і долає свої негативні переживання, стреси, життєві кризи й втрату сенсу життя, тим самим наділяючи цінністю релігійну спілку.

Показано на рівні тенденції, що на переживання почуття соціальної та сімейної самотності релігійними жінками впливає формування спільності «Ми - Вони», яка виступає чинником від'єднання та відокремлення себе від загального середовища з прагненням до духовності, високої моральності й любові в єднанні з Богом.

Виявлено, що самотність має зв'язок із показниками взаємостосунків як у соціумі, так і із сім'єю та партнером (подружжям), які зумовлені недостатністю взаємостосунків унаслідок порушення емоційної інтеріоризації жіночо-чоловічої гендерної ролі через негативну оцінку свого образу й відмову від своєї явно вираженої гендерної ідентичності. Також показано на рівні тенденції, що на Я-концепію релігійних жінок впливають принципи й духовно-моральні цінності в релігійних спільнотах, де індивідуалізм - це егоїзм, який є гріхом.

Установлено, що на суб'єктивний чинник «страх залишитися самій» впливає об'єктивний чинник - втратити домінівну в соціальному оточенні групу релігійно налаштованих людей через не виконання установлених правил поведінки - моральності, яка зобов'язує вимоги «ти повинен» як «етичного чинника», являючись регулятором поведінки, формуючи соціально пасивну, схильну до конформізму, «Богоугодну» поведінку особистості.

Також виявлений зв'язок між самотністю та індивідуально-особистісними рисами релігійних жінок, а саме з некмітливістю, недружністю, відчаєм і розгубленістю, які є наслідком їхньої закритості й усамітнення в соціальному середовищі.

Розглянуто, що потреби й мотиви жінок-вірян у безпеці, в повазі з боку інших і в умінні співвідносити свої бажання, можливості й прагнення до здійснення мети задовольняються ні в соціумі, ні з партнером, а саме в спілці релігійних осіб, де релігія забезпечує безпеку вірянину, компенсуючи отримання поваги й своєї цінності істинною вірою, сприяючи суб'єктивному сприйманню власного добробуту.

Установлено, що самотність (сімейна, романтична) і страх залишитись самій пов'язаніз особистісними причинами й установками страху й тривоги, які виступають бар'єром у спілкуванні, саморозкритті, взаєморозумінні, в повазі, емоційних контактах, у відкритості - можливості іншим зрозуміти й прийняти їх. Отже, через пригніченість і нереалізованість цих потреб особистісне зростання та становлення самосвідомості, ідентифікація особистості, об'єктивізація самооцінки в релігійних жінок блокується, спричиняючи виникнення психологічних проблем, таких як депресія, відчай, бажання ізолюватись від оточення.

Компенсаторною функцією починає виступати релігія, де, підпорядковуючись загальним нормам і вимогам моральності, присвячуючи своє життя Богу, жінка втрачає саму себе, свою унікальність, тим самим отримуючи від спілки релігійних людей підтримку й розуміння, знижуючи переживання страху, тривоги, депресії тощо.

Таким чином, результати кореляційного аналізу показників самотності виявили, що не тільки суб'єктивні чинники впливають на самотність релігійних жінок, а й об'єктивні 
(соціальні) чинники - спілка релігійних людей із встановленими нормами, установками, духовно-моральними ідеалами моральності.

Перспективами подальших досліджень може бути прогнозування та виявлення прихованих взаємозв'язків у змінних, які впливають на підвищення або пониження рівня самотності релігійних жінок, за допомогою регресійного й дисперсійного аналізу, а також порівняння переживання почуття самотності жінками з інших соціальних груп.

\section{ЛІТЕРАТУРА:}

1. Борунков Ю.Ф., Яблоков И.Н., Никифроров К.И. Основы религиоведения : Учебник. 3-е изд. Москва : Высшая школа, 2001. 480 с.

2. Донцов А.И. Особенности влияния религиозных институтов на формирование ценностно-нравственной сореры и семейных установок личности. Поддержка семьи в условиях кризиса : материалы IX Всерос. науч. конф. Новосибирск, 2010. С. 187-196.

3. Колякина Е.А. Определение сущности понятия религиозность. Вестник Костромского государственного университета им. Н.А. Некрасова. Сер. Гуманитарные науки: Педагогика. Психология. Социальная работа. Акмеология. Ювенология. Социокинетика. 2007. № 3. Том 13. С. 51-55.

4. Кржевов В.С. Проблема культуры толерантности поведения в условиях глобальной трансорормации. Толерантность в обществе различий : коллективная монография / под редакцией
В.Е. Кемерова, Т.Х. Керимова, А.Ю. Зенковой. Екатеринбург : Полиграсрист, 2005. Вып. 15. С. 41-55.

5. Ольшанский Д.В. Психология масс. Санкт-Петербург : Питер, 2002. 368 с.

6. Сіляєва В.І. Жіноча самотність як психологічна проблема. Практична психологія та соціальна pобота. 2000. № 4. С. 33-35.

7. Симеонова Л. Человек рядом. Москва, 1989. C. 11.

8. Титаренко А.И. Анти идеи: Опыт социально-этического анализа. Москва, 1984. С. 21.

9. Харламенкова Н.Е., Бабанова И.В. Стратегии самоутверждения и ценностные предпочтения одинокого человека. Психологический журнал. 1999. T. 20. № 2. C. 21-28.

10. Швалб Ю.М., Данчева О.В. Одиночество: социально-психологические проблемы. Киев : Изд-во «Україна», 1991. 270 с.

11. Широкалова Г.С. Сравнительные характеристики верующих и неверующих нижегородцев. Социологическое исследование. Москва, 2001. № 7. С. 80-88.

12. Argyle M. Psychology and religion an introduction: Library of Congress Cataloging in Publication Data. USA, Canada : Routledge, 2000. 233 p.

13. Emmons R.A., Paloutzian R.F. The Psychology of Religion. Annual Review of Psychology. 2003. Vol. 54 P. 377-402. DOI: https://doi.org/10.1146/ annurev.psych.54.101601.145024.

14. Peterson C., Seligman M.E.P. The VIA Taxonomy of Human Strengths and Virtues. Washington, DC : Am. Psychol. Assoc, 2002. 